Tér és Társadalom 2. évf. 1988/1. 3-18. p.

\title{
TANULMÁNYOK
}

1988, 2, évf. 1. sz. pp. 3-18.

NAGY LAJOS:

\section{A FEKVÉSI JÁRADÉK ÉS A FÖLDÉRTÉKELÉS KAPCSOLATARÓL*}

A hetvenes évektől kezdve a járadékelmélet újra „feléledt poraiból”. Többek között azért, mert kiderült, hogy a termelöerök fejlödése nemcsak a természet feletti uralmat növelte, hanem pusztitotta is azt: a természeti tényezök nagy része nem újratermelhető (ásványi anyagok, energiahordozók), a reprodukálható természeti eröforrások (a termóföld) mennyisége is csökken, s nem utolsósorban a müanyagok nagy részének "alapnyersanyaga" is természetes anyag. Ezenkívü! a földjáradékelmélet azért is ",megelevenedett", mert mindinkább felismerik azokat az elméleti lehetőségeket, amelyeket a modern monopolista árelmélet megértéséhez nyújt. Az abszolút és különbözeti járadékot felhasználják az ún. innovációs járadékok kidolgozásánál. ${ }^{1}$

A szocialista gazdaságban is megvan a gazdasági viszonyokban gyökerezö létalapja a járadéknak. Ez pedig a föld, mint a gazdálkodás tárgyának a monopóliuma: saját tulajdonú-használatú földön gazdálkodnak a szocialista gazdasági egységek, amelyek gazdaságilag elkülönültek. Ezért a szocialista termelési viszonyok specifikumának figyelembevételével a kapitalizmusra kidolgozott marxi különbözeti járadékelmélet adaptálható a szocializmusra is. Magyarországon a földjövedelem-elméletet napjainkban időszerüvé tette az új földértékelési rendszer kidolgozásának igénye.

A járadékelméleten belül a fekvési járadék meglehetősen elhanyagolt volt. Ez nagyrészt azzal magyarázható, hogy az angol klasszikus gazdaságtan, de Marx is csak „mellékvágányon" foglalkozott a fekvési járadékkal, ennek keretében is a telekés épitési járadékkal részletesebben.

Mivel magyarázható ez? Egyrészt azzal, hogy a fekvési járadékot hasonlónak vették a termékenységi járadékkal, amely semmilyen új szempontot nem visz a järadékelméletbe. Másrészt azzal, hogy a fekvési járadék nem jelent naturális-hozamtöbbletet, hanem csak pénztöbbletként jelenik meg. A fekvési járadék nem természeti tényezókkel kapcsolatos, hanem éppen társadalmiakkal: urbanizációs-civilizációs-infrastrukturális tényezőkke!. Azért tekintik csupán járadéknak, mert a vállalatok, szövetkezetek számára a fekvés objektívabb feltételt képez, mint a fejlesztési és folyamatos ráfordítások.

* A tanulmány az MTA Közgazdasági Intézete felkérésére az 1983 óta folyó komplex földértékelési munkálatok keretében készült. 


\section{A fekvési járadék a marxi járadékelméletben}

A marxi fekvési járadékelmélet alapjai már megszülettek a ricardoi járadékfelfogás „normál esetének”, a leszálló sorrendnek a bírálata során. Ezzel Marx „mozaikszerüen" az Értéktöbbletelméletek II. munkájában foglalkozik, átfogóbb és letisztultabb formában pedig A tőke III. kötetében. A fekvés tágabb felfogása Marxnál nemcsak a gazdaságok elhelyezkedését jelenti, hanem azt is, hogy a gazdaságok különbözó fejlettségü országrészekben helyezkednek el. ${ }^{2}$ A fekvésnek egy kevésbé ismert esetére is utal Marx, amikor a rosszabb termékenységü földek „benyúlnak" a jobb földek közé. A föld-komplexumoknak is vannak jobb és silányabb darabjai, a rosszabb földet már a jobb földdel való kapcsolata miatt is mủvelésbe kell venni. A rossabb termékenység tehát sajátos fekvésbeli elónnyel párosul. Ugyanez a helyzet akkor is, ha a jó termékenységü földek közelében rossz termékenységúek fekszenek, de közöttük természetes viziutak vannak. ${ }^{3}$ Ilyenkor a jó termékenységü földről térnek át a rossz termékenységüre.

A megmüvelt földek kiterjesztése különbözö arányokban történik a földkomplexum összetétele szerint: jókra, közepesekre és rosszakra. Ez azonban nem szabad választásból történik: függ a mezőgazdasági árszínvonaltól. (Nem a rossz föld ráfordításai emelik az árat, hanem a magasabb ár biztositja a rosszabb föld megmüvelését.) Továbbá, mint említettük, a jó fekvés a rosszabb termékenységú földmegmüvelést hozza magával.

Mivel foglalhatjuk össze Marx fekvési járadékra vonatkozó nézeteit?

a) A fekvésnek két tekintetben szán kiemelkedỏ szerepet: a gyarmatokon (sok szabad földterület) és a földek müvelésbe vétele sorrendjének megállapításánál.

b) A különbözeti járadék két oka a termékenység és fekvés ellentétes irányban is hathatnak. (Jó a fekvés, de rossz a termékenység.) De hathatnak egyirányban is. (Jó fekvés és magas termékenység.)

c) A társadalmi termelés haladása két ellentétes hatást gyakorol a fekvésre. Egyrészt nivellálóan hat: helyi piacok létrehozása, közlekedési eszközök és utak fejlődése, másrészt növeli a fekvési tényező hatását: azáltal, hogy a technikai-gazdasági munkamegosztás elválasztja az ipart és a mezógazdaságot, kialakítja a nagyvárosokat, elszigeteli a falut.

Marx a termelékenységet és a fekvést megvizsgálta a piaci ár alakulása viszonyában is. A piaci ár növekedése magasabb termékenységü földek müvelését eredményezi, amelyeket korábban a rossz fekvés miatt nem müveltek meg. Vagy a terméketlenebb föld fekvési elônyeit fokozhatja úgy, hogy kiegyenlíti a csekély termékenységet. A piaci ár változatlansága esetén a föld fekvésének javulása lehetóvé teszi a jobb termékenységú földek müvelésbe vételét. Marx a következőkkel zárja a fekvési járadékkal foglalkozó gondolatait: „a földek fekvésének és termékenységének ellentmondó hatásai, s a fekvési tényezó változékonysága - amely tényezó állandóan kiegyenlítődik - váltakozva hol ugyanolyan jó, hol jobb, hol rosszabb új földdara. bokat hoznak új konkurrenciába a régebben megmúvelt földekkel". 4 


\section{Fekvési járadék a szocializmusban}

A szocialista viszonyok közepette is a földminöség egyik meghatározója a termelékenység mellett a fekvés. Ha nem is természeti termelőerőt, de objektiv tényezöt jelent, amely hosszabb távon ugyan változik, de rövidebb távon hat a ráfordításokra és az árbevételre, igr a tiszta jövedelem nagyságára.

Mivel a szocialista földtulajdonon, illetve használaton alapuló gazdálkodás saját gazdálkodásnak számít és nem bérleti rendszernek, a fekvési járadék sem különül el tulajdonilag, része a vállalati jövedelemnek. Továbbá a fekvési járadékot - most eltekintve az elvonástól - a gazdasági egységek realizálják éppen a köztük lévő tulajdoni elkülönültség miatt. A szocialista árutermelés alapján keletkezik tehát a fekvési járadék a jövedelemtermelö képesség különbségeként. A termelését (nincs idegen munka valamely osztály általi elsajátítása) és elosztását (amennyiben ez a járadék vállalati kollektívák egymás közötti, illetve a kollektívák és az állam viszonya) a szocialista termelési viszonyok specifikumai határozzák meg.

a) A fekvési járadéknak sajátossága az, hogy elsősorban nem a természeti, hanem fekvési tényezőkkel függ össze, amelyek, ha nem is változatlanok hosszú távon, de objektívek, a termelötöl függetlenek.

b) A fekvési járadék keletkezésében gazdasági és természeti tényezók együttesen játszanak szerepet. A fekvési járadék, noha összefügg természeti tényezőkkel (például a domborzati viszonyok, a földfelszín tagoltsága hat a szálítás formáira, a talajszerkezet hatása az útviszonyokra), mégis alapvetó szerepe a gazdasági tényezóknek van: az urbanizáció és infrastruktúra fejlödése, a termelés területi elhelyezése, a társadalom egészének munkaráfordítása. A fekvési járadék sajátossága az is, hogy nem a közvetlen termelésben, hanem a tágan vett termelés végső szakaszában, a szállításban vagy az értékesítésben keletkezik. Ez utóbbihoz csak annyit, hogy ennél a fekvési járadék tágabb fogalom, mert nemcsak az értékesítési-szállítás, hanem a beszerzési-szállítás, sőt a termelésbe integrált belsó szállitás hatását tartalmazza, ez pedig a közvetlen termelés mozzanata.

Van-e a fekvési járadéknak anyagi és jövedelmi alapja? E kérdésre az a válasz adható, hogy a fekvési járadék csak tisztajövedelem-többletként (költségcsökkentésként), pénzfolyamatként, vagy amellett termék-hozamtöbbletként, reálfolyamatként keletkezik. A modern árutermelésben a gazdasági folyamatok kettőssége megtalálható: pénzfolyamat (értsd: pénz és ármozgás) és reálfolyamat (értsd: naturális, használati érték illetve érték-mennyiségi folyamat). Hiszen az értéket alkotó elemek mögött legtöbbször használati értéktömeg található. A fekvési járadékra is e folyamatok kategóriája alkalmazható. Tehát a fekvési járadék nemcsak jövedelemtöbbletként, hanem terméktöbbletként is kezelhetó. Ha ugyanis a szállítási költségek a közeli piac miatt alacsonyabbak valamely vállalatban, akkor a teljes ráforditás nagyobb hányada a közvetlen termelési és kisebb hányada a szállitási ráfordítás, így a termelést növelni lehet. Ehhez azonban meg kell jegyeznünk egyfelöl, hogy ez csak statikusan igaz, mert a közvetlen termelés számára felszabaduló szállítási ráfordítás. megtakarítást nem biztos, hogy az adott gazdaság változatlan hatékonysággal be tudja fektetni. Másfelöl a szállításnak vannak tiszta forgalmi költségei is, amelyek az új érték és így a fekvési járadék terhére is megtérülhetnek. 
A szocialista gazdaságban is vannak a fekvési járadék csökkenése irányába ható tényezők: a) a szállitási költségek megtérítése, b) a felvásárló szervek közeltelepítése a termelő gazdaságokhoz, c) az ipari és a mezógazdasági termelés tervszerü területi elhelyezése.

Melyek a fekvési járadék növekedése irányába ható tényezők? a) A termelés specializációja következtében a belső termelö felhasználás csökkenése, az áruértéke. sítés növekedése. b) A mezögazdasági termelésben az ipari munka arányának jelentós növelése. c) A vállalati méretek jelentös megnövekedése. ${ }^{5}$

A fekvési járadék lényegéröl és alakulásáról a magyar közgazdasági irodalomban is viták alakultak ki. ${ }^{6}$ Ennek egvik kérdése az volt, hogy mennyiben sajátos a különbözeti I. sz. járadék termékenységi és fekvési formája (igazi vagy átmeneti járadékforma-e). Ehhez kapcsolódva a másik kérdés az volt, hogy van-e a fekvési járadéknak is anyagi alapja.

Milyen tényezöktől függ a fekvési járadék?

a) Minden, a fekvéssel összefüggö ráfordítás-különbségtöl. A szállitási költséget befolyásoló tényezőktôl: a piactól való távolságtól, az utak minőségétöl, a rendelkezésre álló szállítóeszköztől (közút, vasút, viziút stb.). Ugyanis, ha a szállitási költségek a jobb fekvés miatt alacsonyabbak, különbözeti fekvési jövedelem vagy különbözeti fekvési veszteség keletkezik. (lde tartozik az is, hogyha a kisebb szállitási távolságok miatt csökkennek a vállalati veszteségek.)

b) Minden, a fekvéssel összefüggö árbevétel-különbözettöl: a piachóz való közelség kedvezőbb jövedelmezőségü termelési struktúrát tesz lehetővé, vagy a vá. roshoz közelség magasabb árakat biztosít (például szabadpiaci árakon történhet az értékesítés).

c) A szállítási költségek különbségére, így a fekvési járadékra hatnak egyéb - nem túl jelentős, de nem is elhanyagolható - tényezök. Néhányat ezek közül:

A nyugdijasok aránya a termelószövetkezetekben, hiszen a nyugdíjasoknak nyújtott természetbeni szolgáltatások szállítási költségei eltérőek a szállítási távolság és a nyugdíjasok aránya miatt. (Például 40-60\% lehet a nyugdíjasok aránya és a számukra történő szállitás 15-25 q-át tehet ki évenként.) Ez alapvetően speciális öszszetétellel összefüggó kérdés, de bizonyos fekvési elemek is szerepet játszhatnak benne. Például a nagy területü szövetkezetekben nyilván nagyobbak a szolgáltatás szállitási költségei. Ide tartozik az is, ha a jó fekvés nagyobb területek olcsóbb öntözését biztosítja.

A legnagyobb szerepe azonban a fekvéssel összefüggő szállitási költségeknek van a fekvési járadék keletkezésében.

A szállitási ráfordításokat azonban az elöbbiekben nagyon leszükitettük. Ugyanis ide tartoznak a következök: Elöször, a mezögazdasági vállalatok (szövetkezetek) értékesitési szállításai (árfelvásárló-feldolgozó-kereskedelmi egységeknek). Ezt a kiszállitásnak nevezzük a továbbiakban.) Másodszor, a mezógazdasági gazdasági egységek beszerzési-szállításai. (Ezt nevezzük beszállitásnak.) 


\section{NAGY LAJOS:

\section{A fekvési járadék figyelembevétele a jelenlegi földértékelésben}

Befejezéshez közeledik hazánkban a földértékelési munka, amely hivatott lesz az "évszázados" aranykorona rendszert felváltani a termóhelyi értékszámon ${ }^{7}$ alapuló gazdasági földértékeléssel. A termöhelyi értékszámhoz kiszámítják a növénytermelés területegységére jutó összes tisztajövedelmet, ebböl levonják a lekötött tökejövedelmet, meghatározott kamattal számolva, a maradék a földjövedelem.

A földértékelési folyamatnak egyik dilemmáját képezi az, hogy átlagos termőhelyi értékszámmal bíró gazdaságokban a területegységre számított földjövedelem nagysága jelentösen (például 2-3,5-szeres mértékben is) különbözik egymástól. Kérdés, milyen okai lehetnek ennek?

$\mathrm{Az}$ azonos minöségũ földeken a „földjövedelem" differenciák az eltérő eszközhatékonyság miatt keletkező ideiglenes extrajövedelmekből adódnak. Joggal élhetünk azonban azzal a feltételezéssel is, hogy ebben szerepet játszik a fekvési jövedelem is.

Az azonos minóségü földön a földjövedelem három összetevőböl állhat: természeti földjövedelem, fekvési földjövedelem és ideiglenes extrajövedelem. A fek. vési járadék akkor növeli a földjövedelem differenciákat és akkor realizálódhat: ${ }^{8}$ a) ha a negativ, ideiglenes extrajövedelem nem kompenzálja a fekvési jövedelmet, b) ha a természeti földjövedelem hozzáadódik a fekvési jövedelemhez, c) ha az alacsony természeti jövedelem nem „fogyasztja” a fekvési jövedelmet.

Nyilván azok az esetek is felsorolhatók, amikor a fekvési jövedelem csökkenti az össz-földjövedelmet. Mindezek alapján valószínúsithetó, hogy ha valamely vállalatnál (vállalatcsoportnál) a fekvési járadék növelö szerepe, másoknak a csökkentő szerepe érvényesül, akkor ez a kimutatott földjövedelem különbségeit elóidézheti.

\section{Néhány általános megiegyzés a fekvési jövedelem arányáról a földjövedelemben}

A fekvési járadék megközelitéséhez két hipotézist állitottunk fel.

Első hipotézis: a földjövedelem tartalmaz nem elhanyagolható fekvési járadékot. Vagyis nem igaz, hogy a $0 \mathrm{~km}$-es egységes felvásárlási árak miatt a városoktól (piactól) való távolság nem mutat szignifikáns korrelációt a földjövedelemmel, tehát a fekvési járadék nem differenciálja a földjövedelmeket.

Második hipotézis: a fekvési járadék alakulásában a tágan értelmezett szálIitási költségeknek van uralkodó szerepe. Vagyịs a fekvési járadékban szerepet játszó egyéb tényezök hatása jelentéktelenebb.

$A z$ elsó hipotézisról. A folyamatban lévő földértékelési rendszerünk a fekvés és a földjövedelem kapcsolatának hiányát a következőkkel indokolja: a) a $0 \mathrm{~km}$ egységes mezögazdasági felvásárlási árakkal, b) a város körüli élómunkaigényes kultúrák alacsonyabb jövedelmezőségével, c) a város közeli szántóföldi termelés élömunka-költségesebb voltával. A konklúzió: „Jelenlegi ár- és szabályozórendszerünk mellett nem mutatható ki jelentösebb helyzeti járadék."9 A 9 km-es árak, a szállitási költségek megtérítése alapján alakuló felvásárlási árak valóban csökkentik a fek- 
vési járadék szerepét, de nem szüntetik meg. Miért? A nem szerződéses kapcsolatokban folyó értékesítésnél nem térítik meg a szállitási költségeket. A szállítási költségek nagy részének a megtérítése csak a szállítás egyik típusában, az értékesítési szállításban történik meg. A szállítási volumen jelentős részét viszont a másik két szállitási típus teszi ki (belsö- és beszállítás).

A korábbi vizsgálatok a fekvési járadékot a nagyvárosok, a megyeszékhelyektől való $0-50 \mathrm{~km}$ távolság szerint differenciálva kivánták megragadni. Azért nincs összefüggés, mert az értékesítési szállítási távolság és költsége nem a várostól, hanem a felvevő (felvásárló kereskedelem, feldolgozóipar, határállomás) telephelyétól függ. (Például ha $10 \mathrm{~km}$-re van egy gazdaság a várostól, attól még a felvevő helytől lehet $1 \mathrm{~km}-$ re.) Tehát nem a várostól, hanem a piactól való távolság a fontos. De mondhatja valaki, hogy a $0 \mathrm{~km}$-es felvásárlási ár a felvásárló telephelyéig téríti a szállítási költségeket, tehát nem képződnek fekvési járadékok. Ez akkor tükrözné is a valóságot, ha a felvásárló-feldolgozó-értékesítő vállalatok mindig és mindenütt meg. térítenék a szállitási teljesítmény teljes értékét. Ezek monopolhelyzete miatt azon. ban - termesztési termékfajtától, ágazattól függően - gyakran előfordul, hogy csak önköltséget (vagy ennél valaminél többet) térítenek. A felvásárló monopolizáltság, a vállalati termelési struktúra különbözősége és a szállítás típusa befolyásolja a fek. vési járadék szintjét és differenciáját. Végül az, hogy önköltségen vagy a szállítási teljesitmény értékén térítik meg a szállítási költségeket, differenciálja a fekvési jả. radékot (a pozitív, esetleg negatív járadékot), noha formálisan megtérítik a szállitási költségeket.

$\mathrm{Az}$, hogy a piac-közeli termelési szerkezet kevésbé jövedelmezö, élőmunka. igényesebb volta miatt, valóban azzal jár, hogy kisebbek a földjövedelmek. Ez nem jelenti azonban azt, hogy a fekvést meghatározó tényezők a háttérben ne múködnének. Csupán ezekre a tényezőkre már nem osztottunk jövedelmet, mert ezt felemészti a fix kamatlábbal számitott tőke alapjövedelem. Ezen okok miatt nem tudjuk ki. mutatni a fekvési járadékot, amely azonban jelen van az összjövedelem (pozitív vagy negativ) részeként.

A második hipotézis szerint a fekvési járadékot befolyásoló tényezők között a szállitási költségek differenciáinak van alapvető szerepe. ${ }^{10}$ A földértékelés során készült irodalom a fekvési járadék alakulásában négy tényezőt jelöl meg erőteljes hatásúnak: a) a népsúrúség, b) a fövárostól való távolság, c) a regionális központoktól való távolság, d) a vasútsủrủség. ${ }^{11}$

Azzal a megállapításunkkal, hogy az ár- és jövedelemszabályozás a fekvésből keletkezö elönyöket és hátrányokat részben a népgazdaság egészére, illetve más ágazatba csoportosítja át, a fekvési járadék a vállalatokban még objektíven keletkezhet. Csak a realizálása részben nem történik meg. Továbbá azzal a javaslatukkal is egyetértünk, hogy a fekvési járadékot a jövőben realizálhatóvá és a földértékelésben beszámithatóvá kell tenni.

Ugyanakkor úgy vélem, hogy van némi túlzás és logikai ellentmondás: elöször is abban, hogy 18 tényezót szerepeltet, amelyböl 10 a fekvéssel kapcsolatos. A járadékprobléma mégiscsak a természeti tényezők monopolizáltságával függ öszsze. Nyilván, a természeti tényezöket kiterjedten értelmezzük: talaj természetes ter- 


\section{NAGY LAJOS:}

mékenysége, a domborzati viszonyok és a talajfelszin tagoltsága, végül az éghajlat egyaránt ide tartozik.

Másodszor, a különbözeti járadékot meghatározó tényezókhöz sorolja a munkaerő- és állóeszközvolument is és ezek hatékonyságát is. (Például 1 ha-ra jutó nyereséget, amelyek kívül esnek a járadékproblémán, csak annyiban tartoznak ide, hogy ezek a különböző minöségü földön érvényesülnek és a földjövedelem mellett az összjövedelem részei.)

Úgy gondolom - bár a leegyszerüsités veszélyével számolok -, hogy a fekvési járadék problémát a tágan vett szállitási költségalakuláson keresztül lehet megközeliteni. A fekvési tényezők alapvetóen ebben összegeződnek. Természete. sen nem tagadva, hogy más tényezők is hatnak, a már emlitett szabadpiaci magasabb árak, a kisebb szállítási veszteségek stb. Ezek összegeződnek, túlkompenzálhatják vagy részben semlegesíthetik a szállitási költségeket, például egy szatymazi szövetkezet Tatabányára szállitja az őszibarackot, bár nagyobb a szállitási költsége, de ennél magasabb a piaci ár, ám a szállitási költségek domináns szerepét nem szüntetik meg.

Milyen hatással van a népsürüség a fekvési járadékra? Valamely makrokörzet (város, városkörnyezet, körzet) nagyobb népsűrúsége a nagyobb mezőgazdasági termék-kereslet miatt növelheti a piaci árakat. Ám a mi viszonyaink mellett ennek a szerepe meglehetőségen korlátozott a következők miatt: a) Ennek csak az ún. szabadpiaci termékek egy részének az értékesitésénél van jelentös szerepe, amely a növénytermelésnek kis hányada. b) Az ország viszonylag kis területe miatt a távolabbi szál. lítások költsége sem túl nagy, ez növeli a kínálatot e termékek piacán. c) A nagy népsürüség, ha növeli a keresletet, akkor az értékesitési piachoz közel fekvők ezekben a termékekben kétféle fekvési járadékhoz jutnak: piaci járadék (magasabb ár), szállítási járadék (rövidebb szállítási távolság, mivel itt nem térítenek szállítási költséget). Amennyiben nagyobb a távolság a piactól, akkor a vállalat mérlegel a piaci ár és a szállítási költség alapján. Tehát láthatjuk, hogy a népsürúség mint fekvési járadék tényező is kapcsolatos a száltítási költségekkel.

Milyen szerepe van a fekvési járadékban a városoktól la fóvárostól, regonális központoktól, üdülökörzetektöl) való távolságnak és az ettöl függó szállitási költségeknek? Ezt a kérdést már elöbb érintettük: a piac nem azonos a várossal és az értékesitési szállitási költségek az összes szállitási költséggel. Hiszen a felvásárló-feldolgozó vállalatnak lehet a gazdasághoz közel felvevő telephelye. Hiszen a termelöeszköz-kereskedelmi vállalatnak lehet a gazdaság közelében értékesítő telephelye (lerakat, utolsó vasútállomás stb.). Végül a szállításnak lényeges eleme az üzemen belüli szállitás is. Véleményem szerint ezért sem jött ki megfelelö eredmény abból, hogy a különböző városoktól 0-50 km-es távolságok szerint kísérelték meg a fekvés hatását kimutatni. Később látjuk, a városhoz való távolságnak nem hanyagolható el teljesen a \$zerepe, hiszen a termelöeszközök egy részét a gazdaságok a városból szállítják. Továbbá akkor sem, ha az értékesító-szállítási ráfordításokat a vállalatnak különbözö mértékig téritik meg. (Például a teljesítményértéket vagy az önköltséget.)

Milyen szerrepe van a vasútsürüségnek a fekvési járadékban? Ennek a szerepe valóban jelentős, mert a vasúti szállítás a legjelentősebb és költségei is a legkisebbek. Valóban azonos távolságra a vasúton szállítás elönyös, szemben a közúton szállítással. 
A vasúton szállitásnál azért a szállitási költségek különbözó távolságok függvényében alacsonyabb szinten differenciálódnak.

A szállitási költségek különbségei határozzák meg a fekvési járadék hányadát. Más oldalról azonban a szállítási költségeknek vannak olyan részei, amelyek nem a fekvéssel kapcsolatosak. Egyfelöl - mint emlitettük - a szállítási tevékenységben mint „járulékos" termelötevékenységben és ennek költségeiben is szerepelhetnek ideiglenes extrajövedelemsz'erü részek. (Például: a szállitásnak korszerǔek az eszközei és jó a szervezettsége.) Másfelöl a szállítási költségek nemcsak a fekvés gazdasági tényezöitöl függnek, hanem természeti tényezöktöl is. lgy attól, hogy a szállítási módok közül melyik választható (például viziutak felhasználása), attól, hogy - különösen a belső szállitásban - milyenek a domborzati és talajfelszín tagoltságának a viszonyai, attól, hogy a termötalaj minősége milyen „természetes utakat” nyújt a szállitás számára. Tehát a szállitási költségek nemcsak a fekvés-gazdasági, hanem a fekvés-természeti tényezökkel is kapcsolatosak. A fekvési járadék egy része tehát tartalmát tekintve „természeti járadék”. A szállítási költségek két részre választása mégsem indokolt, mert mindkét esetben „monopolizált termelési tényező" járadékszerü jövedelméröl van szó. Összegezésként megállapithatjuk, hogy bár a fekvési járadék több tényezö eredöje, e tényezök többségükben vagy közvetve vagy közvetlenül kapcsolatban vannak a szállítási költségekkel. Ezért nem követünk el nagy hibát, ha a fekvési járadékot ennek alapján ragadjuk meg.

\section{A tágan vett szállítási költségek tipusai és alakulásuk}

A bevezetöben enlitettem, hogy a kérdés tárgyalásánál a logikai analizis módszerét követjük. Mégis szükségességét látjuk annak, hogy néhány gyakorlati tapasztalat fényében is megvizsgáljuk a fekvési járadék kérdését. A Csongrád megyei tapasztalatokat a szállítási költségek alakulásában két metszetben vizsgáljuk: a) A szállitás tipusa szerint: a beszerzési (input) szállítási költségek, a belsö-üzemi szállitási költségek értékesítési (output) szállitási költségek. b) A növénytermelés két vertikuma, a gabona- és kender-vertikum szerint.

Az értékesitési szállitási költségekröl a hatályos rendelkezések a következók: $\mathrm{Az}$ értékesítéssel kapcsolatos belsó szállitásról a legújabb jogszabályok a következöképpen szólnak: „A mezőgazdasági nagyüzem által értékesitett mezőgazdasági termék termelői ára magában foglalja a terméknek a telephely szállítóeszközökkel megközelító részen való összegyüjtésének költségeit". Tehhát a belső szállitásnak nem. csak a termelési szállitással, hanem értékesitési szállitással kapcsolatos eleme is van. A belsö áruszállítás és termelöeszköz-szállitás költségeit viszont nem téritik meg.

Az értékesitéssel kapcsolatos külső szállításról: „A mezögazdasági termékeknek a felvásárló szervezet átvételi helyén történö átadása esetén a mezőgazdasági nagyüzem részére a felvásárló szervezet köteles megtéríteni a következő felmerüló költségeket:

- a mezőgazdasági nagyüzem telephelyétöl az átvételi telephelyig történő útszakaszra - az ármegállapitásban meghatározott kivételektől eltekintve - a fuvardijat (tengelyfuvartérités), 
- az átvételi helyre történö szállítással és az átadással kapcsolatos egyéb szolgáltatások (a szállítóeszközról lerakás, prizmába, vagonba, kazalba rakás stb.) költségeit.

Tehát a felvásárló szervezetek jogilag megtérítik a szállítási költségeket. Azonban a) az ármegállapitásban vannak kivételek, b) az „egyéb”, a szállitással kapcsolatos térités kivételesen elmaradhat.

A fuvardíjtérítés mértékéról a következóképpen intézkedik a jogszabály. A tengely-fuvardíjtérítés mértékében - a Tehergépjármü Díjszabás figyelembevételével - a mezögazdasági termékértékesítési szerződésben kell megáltapodni. A felvásárló szervezet és a mezógazdasági nagyüzemek átalánydíjban, a termény és termék súlyegységére megállapított fuvardijban stb. is megállapodhatnak. ${ }^{12}$ Tehát az or. szágos tarifa figyelembevételével kell a fuvardijat megállapítani, de az átalánydijban és súlyegységben is meg lehet állapodni. Itt már bizonyos vállalati eröviszonyok is bejátszhatnak a fuvardijba. A felvásárló szervezet, ha érdeke megengedi, kihasználhatja ezt.

Vegyük elöször a külsö értékesitö szállításokat. Láttuk, hogy az egységes felvásárlási árak nem tartalmazzák a szállítási költségeket, hanem ezeket a felvásárló szervezetek megteszik. Mit jelent ez a közgazdaságtan nyelvén? Azt, hogy a mezögazdasági árak alacsonyabbak, mint a termelési ráfordítások (a szállítási költségek is ilyenek). Továbbá azt, hogy a fekvési járadékot a jó fekvésü gazdaságokból elvonják (hiszen ezek az átlagosnál kisebb szállitási költséget kapnak), a rossz fekvésü gazdaságoknak kifizetik, ezzel megakadályozzák negatív fekvési járadék keletkezését, ${ }^{13}$ (hiszen az átlagosnál nagyobb szállítási költséghez jutnak). Elvontan és jogilag tehát kikapcsolódik az értékesitési szállításnál a fekvési járadék probléma.

A valóság azonban ennél jóval gazdagabb. Elöször, a gazdaságok között nemcsak a közvetlen termelésben, hanem a szállításban is eltérések vannak a szállítási ráfordítások hatékonyságában (a szállítási tevékenység magasabb technikai színvonala jobb szervezettségü). Ezért ideiglenes extra tisztajövedelem a szállításban is keletkezik. Ha ez nem olyan tartós is, mint a fekvési tényezök, 3-5 évig hatással bír hatnak. Mivel a földjövedelem sincs e jövedelemrészektöl megtisztítva, így - ha nem is alapvetó - oka ez is lehet a jövedelemdifferenciáknak. ${ }^{14}$

Másodszor, már szóltunk róla, hogy bizonyos monopolhelyzetek és egyéb tényezők miatt a mezógazdasági vállalatok nem kapják meg a szállítási teljesitmény értéket (átlagköltség + átlaghaszon), csupán az önköltséget (esetleg ez alatt vagy valamelyest e fölött). Az igy keletkezett jövedelemkülönbségek vizsgálhatók azonos értékesítési szerkezetben és különböző értékesítési szerkezetben. (Lásd az 1. táblázatot.) Ha azonos az értékesitési struktúra (tehát az árutermékek mindegvikénél a szállitási önköltséget térítik meg), a keletkező, de nem realizált fekvési járadék (mivel a felvásárló differenciáltan térít) színvonala alacsonyabb, mint teljes térítésnél. Ezenkivül negativ fekvési hatás is keletkezik, amely a fekvési járadék keletkezésével eltéró irányban differenciálja a jövedelmeket. Ugyanis az önköltségi-szállitási költséggel a rosszabb fekvésú földekról nagyobb értékelvonás történik, mint a jobb fekvésü földekról (225, illetve 75 egység). Ha eltéró a vállalatok értékesitési struktúrája, úgy egyik áruterméknél teljes ráforditást, a másiknál önköltségi ráforditást térítenek; ez még egy tényező, amely a fekvéssel kapcsolatban differenciálja az azonos termékenységü földön képződó földjövedelmet. 

Tér és Társadalom 2. évf. 1988/1. 3-18. p.

$\frac{\mathbb{N}}{2}$

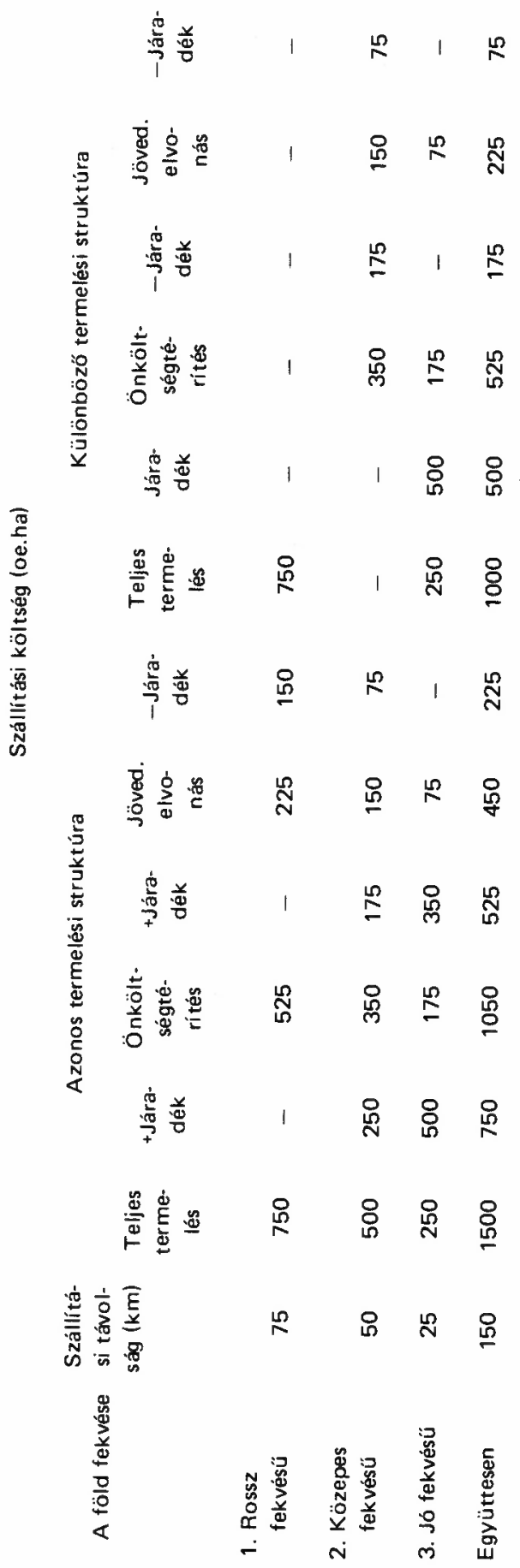


Összegezésképpen: A szállitási költségek megtéritése a vállalatok számára tehát nem jelenti azt, hogy az értékesítésben teljesen kiküszöbölödik a fekvés szerepe. Amennyiben nem térítik meg a teljesítmény értékét a szállításban és eltérő az ebböl a szempontból vett értékesítési struktúra, a fekvési tényezők módosithatják a földjövedelmeket. Megjegyezzük azonban, hogy a mezőgazdasági vállalatok szállitási költségeiben a külső értékesítési szállítások viszonylag kisebb súllyal szerepelnek. Tapasztalati becslés alapján 5-10\%át tehetik ki a vállalati össz-szállitási költségeknek. Tehát a fekvés oldaláról ható tényezők közül nem ezek a dominánsak.

Vegyük most sorra a beszerzési-szállítások költségeit. Ismert, hogy a mezögazdasági termelés iparosítása, az ipar és a mezőgazdaság közötti specializáció elörehaladása megnöveli a mezógazdasági lekötött és folyamatos ráfordításokban a külsó ipari eredetü eszközök és anyagok szerepét. (Ennek aránya napjainkban mintegy 50-58 \%.) Mindezek megnövelik a beszállitások volumenét. A beszállitási kö/tség azonban nem nö olyan mértékben, mint amilyen mértékben az ipari eredetủ költségek nőnek a mezőgazdasági költségekben. Mindez a mezőgazdaságban felhasznált ipari eszközök eltérő technikai jellemzöivel, továbbá azzal is összefügg, hogy a beszerzési-szállítási. költségek jelentős részét is vállalják a termelöeszköz-kereskedelmi vállalatok. Igy tapasztalati becslések szerint a beszállítások a vállalati szállítási költségeknek 15-20\%-át teszik ki.

A fekvési járadék képzôdésében a beszerző szállitảsok (például ipari termelöeszköz-beszerzés) azért játszhat - ha nem is alapvetö - szerepet, mert: a) bizonyos ipari eredetü mezőgazdaság által felhasznált termelóeszközök szállításának költségeit teljes egészében a mezógazdasági vállalatoknak kell viselniük. b) A szállitási költségeknek csak egy bizonyos hányadát vállalják az értékesítő szervek. (Például a mútrágya szállítási költségeinek.) c) A nagy tömegü termelőeszközök (mütrágya, ipari takarmány stb.) szállítását az értékesító vállalatok rendszerint nem a gazdaság telephelyére viszik, hanem az uto/só vasútá/lomásra, amelynek távolsága ettöl legtöbbször különbözö mértékben eltér.

Vegyük végül az üzemi be/só szállitási tevékenységet és kö/tségeit. Mennyiben lehet az üzemek belső szállítási feltételeinek és szállitási kö/tségeinek különbségeit fekvési járadék-képzönek tekinteni? Annál is inkább jogos ez a kérdés, mivel a fekvési járadék problémáit a szokásos felfogás leszúkitette az értékesitési szállitás költségdifferenciáira. (A piactól való távolság, úthálózat stb.).

Nyilván a belső szállítás költségeire is hatnak természeti és fekvésbeli tényezők. Amennyiben ezek tartósak és monopolizálhatók - most csak a fekvési tényezőket vizsgálva -, akkor járadékképző szerepük van. A belső szállítási távolságok eltérése részben az üzemen belüli értékesítési szállitásoknál mutatkozik. (Például a termények beszállítása a földről az üzemi telephelyekre, raktárak, átvevő telephelyei az üzemen belül stb.). Részben az ipari eredetú termelőeszközök szállitása az üzemi telephelyekröl a termelési területekre. Részben a mezógazdasági termelöeszközök szállitása az üzemen belül. A gyakorlati tapasztalatok szerint a szállítási költségeknek a belsö üzemi szállítás teszi ki a dandár részét, mintegy 70-80\%-át. Nemcsak azért, mert itt a szállitandó volumen is a legnagyobb, hanem inkább azért, mert ezeket a szállitási kö/tségeket, eltéróen az értékesitési és a beszerzési szállitástól, nem térítik meg a külsö szervek. 
A belsö szállitás három részköltségének különbsége az egyes gazdaságokban összegezödhet vagy eliminálódhat más gazdaságokban. Igy a fekvéssel összefüggó járadékot eredményezhet. Miból ađódnak azok a különbségek a gazdaságok között, amelyek az üzemen belüli fekvésbeli (szállitási) tényezőkkel kapcsolatosak?

a) Mindenekelött az üzemek nagyságának növekedéséböl és ezen a bázison az üzemek nagyságában mutatkozó eltérésekböl. Ez jelentós különbségekkel jár a szállitási távolságokban és költségekben.

b) Mindezek önmagukban még nem eredményeznének fekvési járadékot akkor, ha a szállitással, felvásárlással, értékesitéssel, raktározással összefüggó infrastrukturális létesítmények a különbözö üzemekben egyenletesen helyezkednének el. Ez azonban nem lehet reális feltételezés. Hiszen az áruszállitással kapcsolatos átadó-átvevő telephelyek elhelyezése és sürüsége nem egyenletes a különböző üzemekben. Hiszen a belső szállitás eszközeinek diszponáló helyei is egyenlötlenül vannak a különböző üzemeken belül elhelyezve.

c) A belső szállitásnak e három altípusát a felvásárlási árak sem tartalmazzák, és a felvásárló-értékesitö szervek sem téritik meg. Ezek a termelési költségeket és így a tisztajövedelmet differenciálják. Véleményem szerint itt kereshetö a fekvési járadék fó fészke. (Lásd a 2. táblázatot.)

2. táblázat

A beszerzési-szállitások volumenének és költségeinek megoszlása Csongrád megyében

Agrokereskedelmi vállalat

Megnevezés

\begin{tabular}{|c|c|c|c|c|c|c|c|c|}
\hline \multirow[t]{2}{*}{ Megnevezés } & meny- & \multicolumn{3}{|c|}{ szállítási } & men $y$ - & \multicolumn{3}{|c|}{ szállitási } \\
\hline & $\begin{array}{c}\text { nyiség } \\
\text { (ezer q) }\end{array}$ & $\%$ & $\begin{array}{c}\text { költség } \\
\text { (ezer Ft) }\end{array}$ & $\%$ & $\begin{array}{c}\text { nyiség } \\
\text { (ezer q) }\end{array}$ & $\%$ & $\begin{array}{c}\text { költség } \\
\text { (ezer Ft) }\end{array}$ & $\%$ \\
\hline Mútrágya & 600 & 38 & 33,000 & 87 & $200^{1}$ & 17 & $2750^{2}$ & 54 \\
\hline Gép-és alkatrész & 470 & 29 & 2,600 & 7 & 470 & 29 & $1300^{3}$ & 25 \\
\hline Növényvédöszer & 350 & 22. & 820 & 2 & 350 & 29 & 410 & 8 \\
\hline Vegyes & 180 & 11 & 1,300 & 4 & 180 & 15 & 650 & 13 \\
\hline Összesen & 1600 & 100 & 37,720 & 100 & 1200 & 100 & 5110 & 100 \\
\hline
\end{tabular}

Mezógazdasági termelö vállalatok

Forrás: A Csongrád megyei Agroker adatai alapján számítva.

1/ A termeló vállalatok múvi szállítása.

2/ A számitott adat, mivel a termelővállalatoknak a mintegy $30 \%$-kal alacsonyabb vasúti szállítás költségeit térítik, miközben közúton szállítanak.

3/ A termelö vállalatok szállítása rövidebb távú, mint a kereskedelmi vállalatoké, ugyanakkor szál. lítási költségei magasabbak.

E becslés-szerü adatok is rámutatnak arra, hogy

a) a mezógazđaságban az ipari termelöeszköz beszállításának mintegy $62 \%$-át a mezögazdaság látja el a kereskedelmi telephelytől a gazdaságig. ${ }^{15}$ Sajátos a helyzet a kereskedelmi vállalatok szállitásának nagy részét kitevő mútrágyánál, ahol a beszerzési szállitás 1/3-át végzik a mezógazđasági termelók, a múvi kiszolgálás esetén.

b) A beszerzési szállitásoknál azonban nem az a fontos, hogy ki szervezi a szál- 
lításokat, hanem az, hogy ki viseli a szállitási költségeket. Mint láthatjuk, a szállitások költségeit az ipari eszközök jelentős hányadában (gép és -alkatrész, növényvédöszer, vegyes) a kereskedelmi telephelytől a gazdaságig teljes egészében a termelö vállalatok viselik. A szállítási költségek azonban itt jóval alacsonyabbak a rövidebb szállítási távolságok miatt. ${ }^{16}$ A mütrágya - mint a legnagyobb volumenü anyag - szál. lítása itt is sajátos, mivel a mezógazdasági termelő az ipari termelötöl szállit (múvi kiszolgálás), akkor a kereskedelmi vállalat a vasúti szállitás költségeit téríti. A 25-30 \%-kal magasabb közúti szállítás költségei a mezőgazdasági termelöt terhelik. Az igazság kedvéért - és ez nemcsak a beszállitásra vonatkozik - említenünk kell azt is, hogy a szállitási költségek alacsonyabb szintje is járhat elönnyel a termelö vállalat számára: részben akkor, ha ez olyan időszakban történik, amikor a szállitási kapacitását egyébként nem tudnák kihasználni, részben akkor, ha ezzel a szállitási időt le tudja rövidíteni la munkák idöbeni elvégzését, a termékek veszteség nélküli szállitását biztositani tudja).

c) Mindezek megengedik azt a következtetést, hogy a gazdaságok - a nem eihanyagolható társadalmi szállítási költségátvállalás mellett is - a beszerzési szállitásnál jelentös költségeket vállalnak. Mivel ezek a szállitási költségek is differenciálódhatnak vállalatonként, a fekvési járadék anyagi alapját képezik.

Összegezésképpen hangsúlyozzuk, hogy a kérdéshez alapvetöen logikaielemzó módon nyúltunk, a verifikálásnak csak a legkezdetibb lépését, néhány gyakorlati tapasztalattal való szembesítését téve meg. A statisztikai-konkrét verifikálást ezért el kellene végezni. Ezek alapján mire juthatunk?

1. Azonos földminőséghez tartozó gazdaságok eltérö földjövedelem-nagy. sága alapvetöen két tényezővel függhet össze. a) Azonos eszközhatékonyság esetén azzal, hogy a területegységre jutó eszköz (lekötött tökeráforditások) az egyes gazdaságokban azonos minöségü földön jelentösen eltérnek. Ha a tökejövedelmet fix kamatlábbal - mondjuk az összes eszközre 8,5\%-kal - számítjuk, ${ }^{17}$ akkor a „,marad. vány földjövedelem" a területegységre jutó ráforditás-volumentöl függ. Más szóval földjövedelemnek tünik az, amely tulajdonképpen ráfordítás-jövedelem. b) A ráfordítások nagyságát adottnak véve a vállalati jövedelmek nagymértékben differenciálódnak az eszközhatékonyság eltéréséból eredöen is. Más szóval, földjövedelemként jelentkezik az ideiglenes extrajövedelem is.

2. A fekvés-szál/itás konkrét vizsgálata azt valószínüsíti, hogy a földjövedelem sokkal inkább függ a fekvéstól, tartalmaz fekvési jövedelem-elemeket, mint a földértékelés során ezt feltételeztük a $9 \mathrm{~km}$-es felvásárlási árak, illetve a szállitási költségek megtéritésével. Az, hogy a földjövedelmek a városokhoz való távolság szerint nem differenciálódnak, még egyáltalán nem jelenti, hogy nem tartalmaznak fekvési járadékot.

A fekvési járadék megközelítése két mozzanat szerint indokolt.

a) A területegységre jutó szállitási költségek, illetve differenciái alapján. Ugyanis ez tartalmazza a szállitás mindhárom típusának költséghatásait, és területegységre viszonylag könnyen meghatározható.

b) Ha az értékesítési szállításnál a jelenlegi szállitási költségtérités fennmarad, akkor az e tipusú szállításnál a szállitási nyereségek differenciáiból is képződik fekvési járadék. Tehát a költség- és nyereségjáradékot egyaránt számba kell venni. 
c) Amennyiben a földjövedelmek korrelációt mutatnak a szállítási költségekkel, két megoldás lehet: az egyik, korrigáljuk a termőhelyi pontértékszámokat, a másik, korrigáljuk a földjövedelmeket. A második megoldás a jobbnak tünő, mert a fekvés nagyrészt nem természeti tényezö, továbbá a szállitási költségek a mindenkori ár-és jövedelemszabályozásnak a függvénye.

\section{JEGYZETEK}

1. SZABÓ K. 1985: Arányossági elv és érték a modern gazdaságban. Akadémiai Kiadó, Budapest.

2. MARX, K. 1974: A töke III. MEM 25. kötet, Kossuth Könyvkiadó, Budapest, p. 617.

3. PI. Michigan állam rossz talajjal bírt az USA-ban, de folyó és csatorna összeköttetése New York állammal a legnagyobb gabonakivivövé tette.

4. MARX, K.: Uo. p. 725.

5. Lásd: NAGY L. 1964: A földjáradék a termelószövetkezetekben. Közgazdasági és Jogi Könyvkiadó, Budapest.

6. PAPP S. 1967: Különbözeti földjáradék és gazdaságpolitika. Kossuth Könyvkiadó, Budapest.

7. A termöhelyi-értékszám a termöföldnek nagyrészt a természetes tulajdonságait: természetes termékenység, talajtagoltság, domborzatl viszonyok, éghajlati viszonyok, a talaj vízgazdálkodása stb. fejezi ki. Ezeket értékeli 1-100-ig terjedö termöhelyi pontértékekkel. (A természeti és gazdasági tényezö́k szerepét a földértékelésben korábban szinvonalasan tárgyalta: BENET IVÁN - GOCZÁN LÁSZLÓ: Kísérlet új földértékelésre. Közgazdasági Szemle, 1973. 3. sz.)

8. Mindezek az esetek a termékenység és fekvés együttes és ellentétes alakulásával függnek össze.

9. A földek közgazdasági értékelése rendszerének és módszerének kialakításával kapcsolatos feladatokról. A. Földértékelési Tématanács anyaga. 1987.

10. Nyilván vannak a fekvési járadéknak egyéb tényezöi is, igy az öntözött terület nagysága, hiszen a fekvésbeli tényezöktöl is függ ennek megvalósíthatósága és költsége. Az öntözött terület viszonylag alacsony aránya, ill. a ráfordításoknak ebben domináns szerepe miatt ezzel nem foglalkozunk.

11. BERNÁT T. - FERENCZI T. 1983: A földek közgazdasági értékelésének egy megközelítése különös tekintettel a helyzeti járadék számitási lehetóségeire és a szükséges adatkör definiálására. Kézirat.

12. OAÁH és MÉM a mezögazdasági termények, állatok és állati termékek termelési árára vonat. kozó IV/38/1985. ármegállapítása. (ATZOSZ p. 1180.)

13. Feltételezve, hogy a ,határfekvés" nem a legrosszabb fekvés.

14. Ez nyilván igy van akkor, ha a szálítás másik két típusát: a beszerzési és belső szállitást veszszük is.

15. A kereskedelmi vállalatokat a termelömütöl a saját telephelyekig szintén terheli szállítási költség.

16. A kereskedeimi vállalatok átlagos szállitási távolsága $200-250 \mathrm{~km}$, a termelö vállalatoké $50-70 \mathrm{~km}$.

17. Megközelitöen ennyi az álló- és forgóeszköz súlyozott kamatlába a jelenlegi földértékelési javaslatokban. 
NAGY, LAJOS:

\section{ON THE RELATIONSHIP BETWEEN LOCATIONAL RENT AND LAND EVALUATION}

(Summary)

Locational rent has come into prominence nowadays with the requirement of the thrifty use and the protection of natural (and economic) resources. In Hungary it is also necessary to analyse the role of locational rent in the differentiation of entreprise income from land use.

Three points are dealt with in the paper:

(1) In Marx's land rent theory there are two fields where locational rents play a role: in colonies where land is abundant) and in the order of which land is taken into cultivation. Marx also pointed out that progress in societal production leads to two contrasted tendencies, both to equalization and differentiation, in land rents.

(2) Locational rent in the socialism is not regarded as a productive force given by nature but as an objective factor which affects expenditures, income and profit. The paper touches upon the specific features of locational rent within socialism and states that they only change on the long run and both physical and economic factors take part in their evolution.

There are factors which increase and others which decrease locational rent also in the socialist economy. Transportation expenditures have a major impact on the formation of locational rent. They have three components: transportation expenditures related to supply, to marketing and to production.

(3) The paper also deals with the relationship between locational rent and land evaluation. It discusses the proportion of locational rent within land income and the impact of various transportation costs, taken in a wide sense, on locational rent.

Finally, the paper suggests an approach to locational rent on the basis of differentiation in transportation costs and transport profits among spatial units. Statistical surveys and calculations would make it possible to correct land income on the basis of locational rent.

Translated by Eta Daróczi

НАДЬ, ЛАЙОШ:

\section{ОБ ОТНОШЕНИИ РЕНТЫ РАСПОЛОЖЕНИЯ И ОЦЕНКИ ЗЕМЛИ}

(Резюме)

Проблема ренты расположения выдвигается на передний план в наши дни. С одной стороны, это требуется экономным использованием и охраной природных (и экономических) ресурсов. А с другой стороны, в ходе разработки системы оценки земли в Венгрии появляется необходимость изучить, какую роль играет рента расположения в больших разницах между предприятиями в доходах с земли.

В статье рассматривается три вопроса.

1. В марксистской теории ренты рента расположения имеет значение в двух областях: в колониях (где много свободной земли) и в порядке освоения эемель. Маркс объяснил и то, что развитие общественного производства одновременно приводит К двум противоположным тенденциям в отношении ренты: К нивелированию и к дифференцированию. 
2. Рента расположения при социализме, если она и не является природной производительной силой, представляет собой объективный фактор, который влияет на величину затрат, на общий и чистый доход.

В статье излагаются особенности ренты расположения при социапизме, с указанием нд то, что она меняется за относительно длинное время, и что в образовании ренты играют роль как природные так и зкономические факторы. Далее, и в социалистической зконо. мике имеют место те факторы, которые действуют в направлении уменьшения или наобо. рот, увеличения ренты расположения. В величине ренты расположения главное значение имеют транспортные затраты, состоящие из трех частей: затраты на транспорт прн реали. зации, при закупке и при перевозках внутри производства.

3. Статья рассматривает и взаимосвязь ренты расположения и оценки земли. В част ности, определяется удельный вес ренты расположения в доходе с земли, а также влияние отдельных типов транспортных затрат в широком смысле на ренту расположения.

В итоге автор предлагает подход к ренте расположения на основе транспортных расходов на единицу площади и их разниц, а также на основе разниц в прибылях от транспортировки. С применением соответствующих статистических наблюдений и вычислений станоөится возможным ввести коррекции в доходы с земли на основе ренты расположения.

Nepesen: Tamaw Баyкo 